LA-UR- $09-06141$

Approved for public release;

distribution is unlimited.

Title: The Geological, Isotopic, Botanical, Invertebrate, and Lower Vertebrate Contexts for Ardipithecus ramidus

Author(s): Giday WoldeGabriel*, Stanley H. Ambrose, Doris Barboni, Raymonde Bonnefille, Laurent Bremond, Brian Currie, David DeGusta, William K. Hart, Alison M. Murray, Paul R. Renne, M.C. Jolly-Saad, Kathlyn M. Stewart, Tim D. White

*Earth and Environmental Sciences Division, Los Alamos National Laboratory, Los Alamos, NM 87545

Intended for: Science

Los Alamos National Laboratory, an affirmative action/equal opportunity employer, is operated by the Los Alamos National Security, LLC for the National Nuclear Security Administration of the U.S. Department of Energy under contract DE-AC52-06NA25396. By acceptance of this article, the publisher recognizes that the U.S. Government retains a nonexclusive, royalty-free license to publish or reproduce the published form of this contribution, or to allow others to do so, for U.S. Government purposes. Los Alamos National Laboratory requests that the publisher identify this article as work performed under the auspices of the U.S. Department of Energy. Los Alamos National Laboratory strongly supports academic freedom and a researcher's right to publish; as an institution, however, the Laboratory does not endorse the viewpoint of a publication or guarantee its technical correctness.

Form $836(7 / 06)$ 


\title{
The Geological, Isotopic, Botanical, Invertebrate, and Lower Vertebrate Contexts for Ardipithecus ramidus
}

\author{
Giday WoldeGabriel, Stanley H. Ambrose, Doris Barboni, ${ }_{5}^{2}$ Raymonde Bonnefille, Laurent
} Bremond, Brian Currie, David DeGusta, William K. Hart, Alison M. Murray, Paul R. Renne, M.C. Jolly-Saad, Kathlyn M.Stewart, Tim D. White

Earth Environmental Sciences Division, Los Alamos National Laboratory, Los Alamos, New Mexico 87545, USA. Department of Anthropology, University of Illinois, Urbana, Illinois 61801,USA.

CEREGE (UMR6635 CNRS/Université Aix-Marseille), BP80, F-13545 Aix-en-Provence cedex 4, France.

Center for Bio-Archaeology and Ecology (UMR5059 CNRS/Université Montpellier 2/EPHE), Institut de Botanique, F-34090 Montpellier, France. Department of Geology, Miami University, Oxford, Ohio 45056, USA.

Department of Anthropology, Stanford University, Stanford, CA 94305-2034, USA.

${ }_{8}^{7}$ Department of Biological Sciences, University of Alberta, Edmonton AB T6G2E9, Canada.

Berkeley Geochronology Center, 2455 Ridge Road, Berkeley, California 94709, and Department of Earth and Planetary Science, University of California atBerkeley, Berkeley, CA 94720, USA.

Université Paris-Ouest La Défense, Centre Henri Elhaï, 200 Avenue de la

République, 92001 Nanterre, France. Paleobiology, Canadian Museum of Nature, Ottawa, K1P 6P4, Canada.

11

Human Evolution Research Center, and Department of Integrative Biology,

3101 Valley Life Sciences Building, the University of California at Berkeley,Berkeley, CA 94720, USA

*To whom correspondence should be addressed. E-mail: timwhite@berkeley.edu

Sediments containing A. $r$. were deposited 4.4 million years ago (Ma) on an alluvial floodplain in Ethiopia's western Afar rift. The hominid-bearing unit is sandwiched between two volcanic tuffs, that have nearly identical Ar/Ar ages and is now exposed across a $>9 \mathrm{~km}$ structural arc. Geological data, and floral, invertebrate, and vertebrate paleontological evidence, along with phytoliths and oxygen and carbon stable isotopes of pedogenic carbonates imply that the hominids inhabited humid cool grassy to open woodlands..

A. $r$. and its associated fossils were recovered from rocks in the Central Awash Complex (CAC) of the Middle Awash, a complexly faulted dome centered $25 \mathrm{~km}$ east of the western rift margin, Africa. Today, $300 \mathrm{~m}$ of strata deposited between 5.6 and $3.9 \mathrm{Ma}$ crop out/are exposed here (1). The Aramis Member of the Sagantole Formation, which contains the hominid fossils, lies midway in this stratigraphic succession, exposed along an erosional arc $>9 \mathrm{~km}$ across extending from the Ounda Sagantole drainage in the southeast to Aramis Locality 6 in the north and Kuseralee Locality 2 to the southwest (Fig. 1). Here, we describe the geology of the region and present isotopic data and paleobotanical and invertebrate fossil data that illuminate the habitat of this region, including near where the hominid fossils were found. 


\section{Geology}

The Aramis member directly overlies the Gàala Tuff Complex (GATC), which has an ${ }^{40} \mathrm{Ar} /{ }^{39} \mathrm{Ar}$ age of $4.419 \pm 0.068 \mathrm{Ma}(2,3)$. This vitric tuff is $0.5-2 \mathrm{~m}$ thick and rich in pumice and crystals. The Aramis member includes light salmon (hue 5YR) to deep red-brown silt, clay, and sand of variable thickness and induration deposited on a floodplain. These strata, which are 3-6 m thick, are overlain by the DaamAatu Basaltic Tuff (DABT), which has an ${ }^{40} \mathrm{Ar} /{ }^{39} \mathrm{Ar}$ age of $4.416 \pm 0.031 \mathrm{Ma}(\mathrm{l})$. We recovered and cataloged more than 6,000 vertebrate fossils from Aramis Member strata between these widespread volcanic marker horizons over an area of....or exentding ... km east to west. These specimens are accompanied by local sedimentological data, botanical, and invertebrate fossils, and oxygen and carbon isotopic data on pedogenic carbonates in soil horizons.

The Middle Awash was a persistent sedimentary basin during the Pliocene (4). The basin axis during deposition of the lower Aramis Member was southeast of the fossil localities: deltaic and lake margin deposits are generally to the east, in the direction of paleocurrent orientations, and erosional features.. Active volcanic centers were located to the south (I). Paleoenvironmental data and structural reconstructions suggest that the elevation may have been slightly higher than today's c. 600 $\mathrm{m}$, although kinematic models are equivocal (5-6).

The lower tuff is underlain by a widespread cobble conglomerate. Its thickness generally increases eastward from an average of $3 \mathrm{~m}$ to up to $6 \mathrm{~m}$.

In the central part of the arc, the fossiliferous sediments are predominantly massive and bioturbated silty clay. Reworked GATC pumices and glass are present locally, but evidence of channels is limited to a few sandstone lenses situated below the fossiliferous strata in thicker intervals. Massive, $<1.5 \mathrm{~m}$ thick, predominantly micritic carbonate horizons and nodules representing groundwater and pedogenic deposits pinch out laterally within clayey silts. These are also locally fossiliferous.

The carbonate deposits contain characteristic features of tufas (7), such as fossil gastropods and other invertebrates; abundant and uncrushed calcite-replaced vegetation; vertebrate remains; and eggshells (guinea-fowl size). These suggest that the carbonate horizons generally formed at or near the landscape surface. Additional evidence of spring activity includes several $1-\mathrm{m}$ wide banded travertine deposits associated with faults near where ARA-VP-6 was collected. A porous carbonate forms a broad, low dome just to the north of this locality.

Paleosols in the Aramis Member [between the two tuffs] are most strongly developed just below the DABT [primarily protosols and calcisols (8)]. Protosols are $10-200 \mathrm{~cm}$ thick, with massive to singlegrain structure and abundant root structures. Calcisols are $50-100 \mathrm{~cm}$ thick and contain subsurface horizons (Bk) displaying massive to angular blocky ped structures, weakly developed argillic cutans, and small ( $<5 \mathrm{~mm}$ across) calcareous nodules and tubules. The best developed calcisols are present directly below the DABT. These nodules are most abundant to the north and may imply that it was slightly drier there. Excavated sections at the southeast end of the arc show weaker soil development perhaps implying deposition in a predominantly wet environment.

The DABT is poorly consolidated. The lower third (c. $15-20 \mathrm{~cm})$ of the unit is composed of bedded and laminated gray basaltic glass lapilli and scoria. Given the geometry of its basal contact and lack of significant scour, we interpret the DABT to have fallen across a dominantly low relief landscape. Reworked clasts of the DABT are seen in only a few small shallow channels. The presence of paleosols and minor channels before deposition of the DABT indicates that sedimentation was intermittent and that streams only slightly incised the basin valley here. Sediments immediately overlying the DABT near the ARA-VP-1(TS), ARA-VP-7, andARA-VP-10 localities contain massive to weak, blocky, root-marked protosols overlain by alternating massive clayey silt and fine, well-sorted sand with tubular, sub-vertical $1-2 \mathrm{~cm}$ burrows. These features indicate that the water table was high and that the floodplain was aggrading more rapidly after deposition of the tuff, in 
accordance with faunal evidence that more aquatic and water-dependent mammals were more abundant.

The time span represented by the fossiliferous sediments between the two tuffs is difficult to ascertain. The dates for the two tephras are statistically indistinguishable, the difference between their dates is $0.003 \pm 0.075$ million years at $68 \%$ confidence. Thus the dates suggest that, most probably, this interval represents a few thousand to perhaps at most 100,000 years. Paleosols in similar aggrading distal floodplain environments generally indicate short time spans (or they do not require long time periods to form). The fossil assemblages collected from throughout the Aramis Member are consistent with environmental stability during its deposition, and evolutionary trends are not evident (9). On the basis of analogous settings, these sediments probably represent deposition within 100 to 10,000 years $(10)$ and their paleontological contents would qualify as a "within-habitat time-averaged assemblage" (11).

The depositional environment of the Ar. ramidus fossils in the CAC differs somewhat from that of penecontemporaneous Gona primate fossils ca. $70 \mathrm{~km}$ to the northwest. The Gona primate was living in a mixed-habitat fauna along the western basin margin where lake deposits interfinger with small fluvial channels or lap onto active basaltic cones and flows (12).

\section{Stable Isotopes}

To help reconstruct the vegetation and environment near the time of the hominid fossils, we analyzed carbon and oxygen isotopes $(13,14)$ frompaleosol carbonate and carbon isotopes from associated organic matter (Fig. 1; Text S1, Table S1, Fig. S1).

Plants using the $\mathrm{C}_{3}$ photosynthetic pathway (such as trees, shrubs and most herbaceous dicots,) have average $d^{13} \mathrm{C}$ values of $-26.5 \%$. Tropical savanna grasses using the $\mathrm{C}_{4}$ pathway have average $\mathrm{d}^{13} \mathrm{C}$ values of $-12.5 \%$. Decomposing plant organic matter labels the soil with a similar isotopic composition. Soil carbonate $\mathrm{d}^{13} \mathrm{C}$ values are typically enriched by $14-17 \%$ relative to those of organic matter $(15)$. Aramis Member organic $\mathrm{d}^{13} \mathrm{C}$ values range from $-21 \%$ to $-15 \%$, and carbonate $\mathrm{d}^{13} \mathrm{C}$ values range from $-6.5 \%$ to $-0.5 \%$ (Table $\mathrm{S} 1$ ). The mean difference between carbonate and included disseminated organic matter $\mathrm{d}^{13} \mathrm{C}$ values $\left(\mathrm{D}^{13} \mathrm{C}\right)$ is $13.8 \%$ and the median is $14.3 \%$, with in the range expected for well-preserved paleosols $(15)$. These data reflect woodland to grassy woodland savanna floral habitats with $30 \%$ to $70 \% \mathrm{C}_{4}$ plants. Oxygen isotopic data indicate what and are what? Carbonate $\mathrm{d}^{13} \mathrm{C}$ and $\mathrm{d}^{18} \mathrm{O}$ values increase axially, from west to east across this outcrop arc (Fig. 1), reflecting more open, probably grass-dominated habitats for the localities to the east. All the primate fossils, including the many isolated teeth, were found in the western outcrops.

\section{Plant fossils}

Many carbonate horizons between the two tuffs contain abundant calcite-replaced wood and endocarps (Fig. 2). In the non-cemented sediments, these??? are typically decalcified and appear during excavation as white streaks or manganese stains. The ubiquitous fossil wood generally lacks internal structure needed to achieve reliable taxonomic identification except for one specimen attributed to the fig Ficoxylon sp. Endocarps of hackberry fruits attributed to Celtis sp. (IO) are wellpreserved and abundant, but these are easily fossilized $(17,18)$, so these trees cannot be assumed to have dominated the vegetation. Celtis trees are tolerant of a wide range of environmental conditions: their immature leaves are eaten by chimpanzees (19).

We analyzed a variety of silt, clays, and carbonate samples, including splits of the isotopic samples, for pollen, but found none.. However, a few grains were extracted from sediment within the ARAVP-1/401 mandible, and from carbonate matrix encasing seeds and two coprolites associated with ARA-VP-6. The ARA-VP-6 grains are attributed to Myrica $(\mathrm{n}=6)$, Borassus/Hyphaene $(\mathrm{n}=2)$, Poaceae grass $(n=4)$ and Cyperaceae $(n=2)$; and the ARA-VP-1 grains to Borassus/Hyphaene $(n=2)$. 
Myrica, Celtis, and palm tree pollen were recovered both below and above Aramas Member, and were part of the arboreal vegetation in the region between 4 and 5 million years ago.

Contemporaneous pollen data recovered from marine sediment deposited in the Gulf of Aden indicate that these trees were widespread and are associated with other components of today's afromontane flora (20).

Given the paucity of pollen, we searched for phytoliths in the same samples (Fig. 2; Tables S2, S3; Fig.S2). Phytoliths produced by grasses (Poaceae) differ in shape and size from those produced by other plants, including woody dicotyledons (most trees and shrubs)and palms (2l). Their relative abundance versus that of globular phytoliths from woody dicots and palms have been used to estimate tree cover based on refernce assemblages in modern soils (22). We recovered and recognized 96 phytolith types from 38 samples from the strata between the two tuffs. Types included globular ones typical of palms [globular echinate; (23)], woody dicotyledons [globular granulate and smooth, produced by trees and shrubs; (24)], grass silica short cells (64 different types), and grass bulliform and hair cells. We also found sclereids and tracheids, and their ratio-what-indicates what about the abundance of forest (25).

On the basis of the geology, phytoliths, fossils, and isotopic data, we infer that the local Pliocene vegetation included abundant palms and trees or shrubs as well as some open habitat grasses. Some grasses could also be present within semi-deciduous woodlands and open forests for at least part of the year. Palms were present at all localities over the $9 \mathrm{~km}$ outcrop arc but were probably most abundant at (despite potential over-representation) near the locations of the ARAVP-1 and SAG-VP7 fossils.

There is no evidence for either lowland humid Guineo-Congolian rainforest, highland C-3 Pooidae grasses, or subdesertic arid vegetation in the GATC-DABT interval, or from younger or older sediments of the CAC. Evidence for Celtis, Myrica, and palm trees fits well the presence of a groundwater-supported mixed grassland??? and woodland to forest.

The invertebrate fauna of the GATC-DABT Ar. ramidus-bearing biotype (especially ARA-VP-1 and -6) includes fossilized insect larvae, dung beetle broodballs and nests, diverse gastropods, millipedes, and a small centipede (Fig. 3). The millipedes belong to Spirostreptida, a large order common in a wide variety of modern African habitats from savannah to forests. Pupal cases (calcite replaced inclusions weathered from carbonate) are common, but taxonomic identification has not proven possible. Dung beetle brood balls from the Aramas Member average 3-5 cm in diameter, and have 5$7 \mathrm{~mm}$ thick walls. Up to 15 of these have been found together in chambers excavated into host deposits. Rare larger balls up to $7 \mathrm{~cm}$ in diameter indicate a larger species. Dung beetles exist wherever large mammals occur in Africa (26).

Terrestrial gastropods are useful indicators of vegetation patterns, rainfall, altitude, and temperature (27). Because these do not withstand hydraulic transport well, given the embedding fine-grain sediment, the overall land snail assemblage can be considered to be locally derived (28). The presence of millipedes, insect cocoons, and solitary bee brood cells reinforces this conclusion. The most common gastropod (34 of 40 identified specimens) is Maizania from the M. hildebrandti group, followed by Limicolaria sp. $(\mathrm{n}=5)$, and a single specimen of Chlamydarion $\mathrm{cf}$. hians. This Aramis land snail assemblage resembles that of modern groundwater forests, such as the Kibwezi in Kenya (29). This lowland forest in a regionally semi-arid area thrives because it has a high water table, an analogy consistent with geological evidence at Aramis.

Of 275 identified fish specimens associated with Ardipithecus, the dominant genus is the catfish Clarias $(\mathrm{n}=175)$, followed by Barbus $(\mathrm{n}=20)$ and the family Cichlidae $(\mathrm{n}=21)$. These are shallow water fish, the former capable of tolerating highly deoxygenated waters and a wide temperature range.

The giant terrestrial tortoise Geochelonia is present, along with Pelusios (African mud turtle, or hinged terrapin), Cyclanorbinae (flapshell softshell turtle), and Pelomedusa (African helmeted turtle). 
Crocodiles are present and represented by scutes and teeth indistinguishable from extant Nile crocodiles. Remains of lizards, snakes, and frogs were recovered, particularly at the ARA-VP6 microfauna quarry. The Lacertilia sample includes representatives of Varanidae (cf. Varanus) and Iguanidae (cf. chameleons, among others). The Serpentes sample includes at least cf. Pythoninae. Given the marked differences in habitat preferences typically seen even within genera of lizards and snakes, their use in paleoecological reconstruction is limited.

Chelonian, crocodylian, and osteichthyan skeletal elements are readily recognizable even when highly fragmentary, so their abundance (number of identified specimens) in a fossil assemblage is almost always inflated relative to their ecological abundance. Even so, these taxa are rare in the GATC-DABT vertebrate assemblage relative to other Middle Awash strata and other Pliocene hominid localities (except Laetoli). Most of these aquatic species presumably appeared episodically on the Aramis floodplain during times of over-bank flooding, although it is possible that some fish represent raptor meals, an interpretation supported by the lack of articulated elements of these taxa at Ardipithecus localities.

The brief stratigraphic interval between the two tuffs provides a transect across a 4.4 Ma Pliocene landscape. Wooded habitats interspersed with some grassland, particularly toward the east prevailed during this time at Aramis between the rift axis to the east and its elevated margin more than $9 \mathrm{~km}$ away to the west. Here, a largely aggradational plain adjacent to the low northern slopes of the emerging CAC was subject to alluvial flooding. This environment supported the diverse Ardipithecus bearing vertebrate assemblage described in (9) and (29). To the east, farther toward the Afar rift axis, the landscape was more open, with more grass, fewer trees, more or larger bodies of water, but apparently without Ardipithecus.

\section{References and Notes}

1. P. R. Renne, G. WoldeGabriel, W. K. Hart, G. Heiken, T. D. White, Geol. Soc. Am. Bull. 111, 869 (1999).

2. G. WoldeGabriel et al., Nature 371, 330 (1994).

3. T. D. White et al., Nature 440, 883 (2006).

4. Y. Haile-Selassie, G. WoldeGabriel, Ardipithecus kadabba: Late MioceneEvidence from the Middle Awash, Ethiopia (Univ. California Press, Berkeley, 2009).

5. M. Hailemichael, J. Aronson, S. Savin, M. Tevesz, J. Carter, Palaeogeogr.Palaeoclimatol. Palaeoecol. 186, 81 (2002).

6. T. F. Redfield, W. H. Wheeler, M. Often, Earth Planet. Sci. Lett. 216, 383-398(2003).

7. T. D. Ford, H. M. Pedley, Earth Sci. Rev. 41, 117 (1996).

8. G. H. Mack, W.C. James, H.C. Monger, Geol. Soc. Am. Bull. 105, 129 (1993).

9. T. D. White et al., submitted ["Macrovertebrate ..." paper, this suite].

10. A. K. Behrensmeyer, Paleobiol. 8, 211 (1981).

11. S.M. Kidwell, K. W. Flessa, Annu. Rev. Earth Planet. Sci. 24, 433 (1996).

12. J. Quade et al., Geol. Soc. Am. Sp. Pap. 446, 1 (2009).

13. S. Ambrose, N. Sikes, Science 253, 1402 (1991).

14. T. E. Cerling, in Palaeoweathering, Palaeosurfaces and Related Continental Deposits, M. Thiry, R. Simon-Coincon, Eds., (Special Publications of theInternational Association of Sedimentology, 1999), pp. 43-60.

15. T. E. Cerling, Earth Planet. Sci. Lett. 71, 229 (1984).

16. An earlier paper on Aramis (2) attributed these endocarps to Canthium based on identifications by the late R. Dechamps of Belgium. Subsequent work by R.B. revised the identification.

17. R. W. Wrangham, M. E. Rogers, G. Ibasuta, Afr. J. Ecol. 31, 49 (1993).

18. G. J. Retallack, J. Hum. Evol. 29, 53 (1995). 
19. A. H. Jahren, M. L. Gabel, R. Amundson, Palaeogeogr. Palaeoclimatol. Palaeoecol. 138, 259 (1998).

20. R. Bonnefille, R. Potts, F. Chalié, D. Jolly, O. Peyron, Proc. Natl. Acad. Sci. 101,12125 (2004).

21. D. R. Piperno Phytolith Analysis: An Archaeological and GeologicalPerspective. (Academic Press, San Diego, 1988).

22. D. Barboni, L. Bremond, R. Bonnefille, Palaeogeogr. Palaeoclimatol.Palaeoecol. 246, 454 (2007).

23. F. Runge, Rev. Palaeobot. Palynol. 107, 23 (1999).

24. G. Scurfield, C. A. Anderson, E. R. Segnit, Aust. J. Bot. 22, 211 (1974).

25. C. A. E. Stromberg, Palaeogeogr. Palaeoclimatol. Palaeoecol. 207, 239 (2004).

26. I. Hanski, Y. Cambefort, Eds., Dung Beetle Ecology (Princeton Univ. Press, Princeton, 1991).

27. M. Pickford, J. Afr. Earth Sci. 20, 167 (1995).

28. Sparse contaminant lacustrine gastropod taxa are attributable to recent transport of bioclastic sandstone blocks from younger outcrops to the GATC-DABT package by local people building houses, and via construction of the $A R A-V P-6 / 500$ marker platform.

29. A. Louchart et al., submitted ["Taphonomic ..." paper, this suite].

30. For funding, we thank the National Science Foundation (including the Revealing Hominid Origins Initiative/HOMINID program), the Institute of Geophysics and Planetary Physics of the University of California at Los Alamos National Laboratory (LANL), and the Philip and Elaina Hampton Fund forFaculty International Initiatives at Miami University. The Earth and Environmental Sciences Division Electron Microprobe laboratory at LANL assisted with access and use. We thank M. Pickford, H. Hutchinson, and W. Shear for gastropod, chelonian, and millipede identifications, respectively. We thank M. Buchet and X. Prasad for pollen preparations and microscopic observations, and M. Dupéron-Laudouaneix and J. Dupéron for identification of fossil wood. We thank K. Brudvik and H. Gilbert for illustrations. We thank J. Quade, N. Levin, and S. Semaw for discussion and comparative data. We thank the Ministry of Tourism and Culture, the Authority for Research and Conservation of the Cultural Heritage, and the National Museum of Ethiopia for permissions and facilitation. We thank the Afar Regional Government, the Afar people of the Middle Awash, and many other field workers for contributing directly to the research efforts.

\section{Figure Legends}

Fig. 1. Satellite image of the c. $9 \mathrm{~km}$ erosional arc exposing the Ardipithecus-bearing GATC-DABT horizon of the Central Awash Complex of the Middle Awash study area, Ethiopia. Isotopic data are shown. Values in the eastern sample sites indicate more open habitat (where primate fossils were not found), a finding consistent with the macrobotanical and paleontological evidence.

Fig. 2. Fossilized botanical remains from the GATC-DABT interval. Wood and seeds are ubiquitous at the Ardipithecus-bearing localities of the Aramis Member.

(A). Silica bodies (phytoliths). The bilobate (Bi) and polylobate (Po) types are from grasses (Poaceae); the globular echinate (GE) is from palms (Palmae). Scale bar 10 microns. (B) Fossil wood. (C). Tangential microscopic section, general view showing disposition of rays of fossil wood specimen from ARA-VP-6, identified as the fig tree Ficoxylon sp. Scale bar 108 microns. (D) Fossilized Celtis (Hackberry) seeds. Scales: $2 \mathrm{~cm}$ for B and D.

Fig. 3. Fossilized invertebrate remains and traces from the GATC-DABT interval. (A). Gastropods: ARA-VP-6 Maizania sp. (B). Gastropods: ARA-VP-6 Limicolaria sp. (C) Millipedes: ARA-VP-1. (D). Larvae: ARA-VP-6. (E). ARAVP-6 centipede; (F). Dung beetle brood balls and nest, ARA-VP6. 


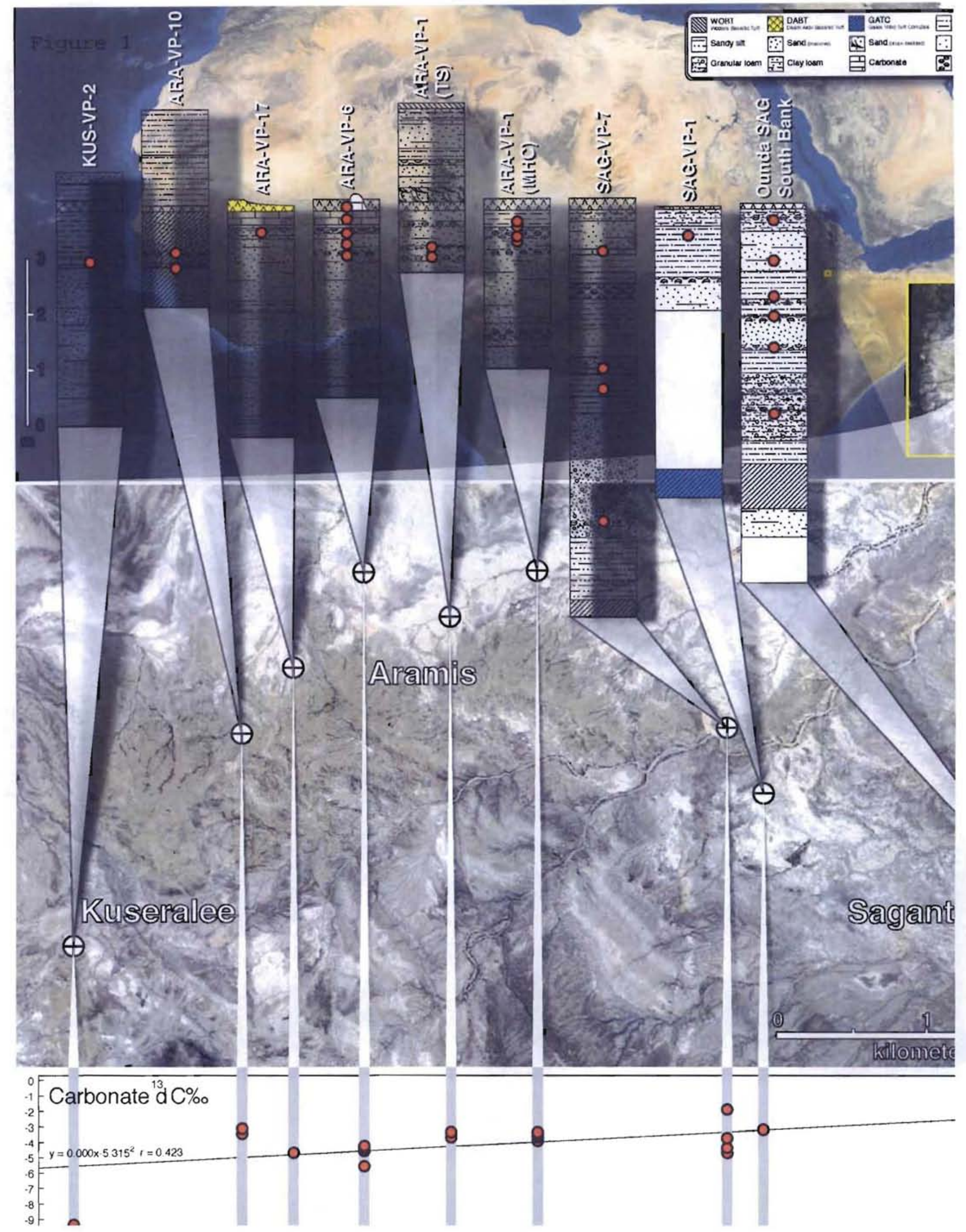



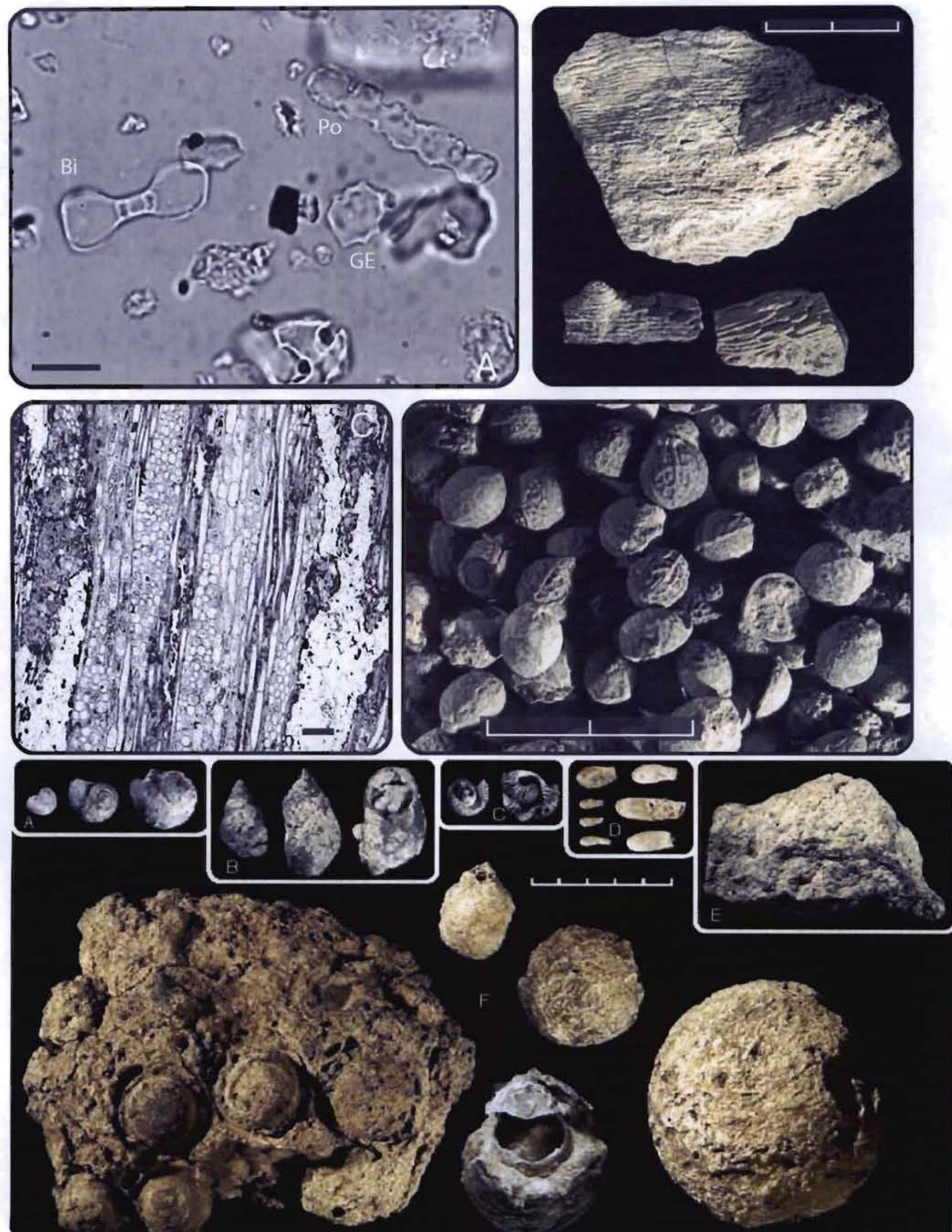


\section{SOM Text}

Text S1. Stable isotope sample collection and analysis.

\section{SOM Figure Legends}

Fig. S1. Paleosol carbon and oxygen isotope ratios with depth. Note that because the thickness of the GATC-DABT interval varies substantially among the different sections plotted here, equal vertical position should not be equated temporally. See text for details.

Fig. S2. Comparison of tree cover densities between modern and fossil samples using: a) the D/P ${ }^{\circ}$ ratio of ligneous dicotyledons phytoliths (globular granulate) versus the Poaceae short cells phytoliths (D/P ${ }^{\circ}$, Bremond et al., 2007), and b) the abundance of arboreal phytoliths (ligneous dicots + palms) relative to the total phytolith abundance (including the silicified bulliform and hair cells of grasses). Mean values, standard error of the mean (SE), and 95\% confidence interval are given for present-day African vegetation types (1).

SOM Table Legends

Table S1. Middle Awash Valley paleosol organic matter and carbonate stable isotopic composition. Table S2. Samples analysed for phytolith and pollen content, with reference to their stratigraphic position relative to the dated Gàala Tuff Complex (GATC) and Daam Aatu Basaltic Tuff(DABT), Sagantole Formation, Middle Awash Valley (Ethiopia). Shaded area indicates samples constrained by the two tuffs. Astericks (*) indicate phytolith sub-categories not distinguished during counting. Phytolith sum includes phytoliths diagnostic for grasses, woody plants, and Cyperaceae. Initials refer to analyst.

Table S3. Data used in constructing Fig. S2. Comparison of tree cover densities between modern and fossil samples using a) the $D / P^{\circ}$ ratio of ligneous dicotyledons phytoliths (globular granulate) versus the Poaceae short cells phytoliths $\left(D / P^{\circ}\right)(2)$, and b) the abundance of arboreal phytoliths (ligneous dicots + palms) relative to the total phytolith abundance (including the silicified bulliform and hair cells of grasses). Mean values, standard error of the mean (SE), and 95\% confidence interval are given for present-day African vegetation types (1).

\section{References and notes}

All refs and notes should be collected together in SOM. see guide.

\section{D. Barboni, L. Bremond, R. Bonnefille, Palaeogr. Palaeocl. Palaeoecol. 246, 454-470 (2007).}

\section{L. Bremond et al., Glob. Planet. Change 61, 209-224 (2008).}

\section{Text S1. Stable isotope sample collection and analysis materials and methods}

Stratigraphic sections were excavated with picks, shovels and trowels in vertebrate paleontology (VP) localities in the Kuseralee Dora, Aramis, and Sagantole areas of the Sagantole Formation in November, 1996. Excavated sections were photographed, measured and described in the field. Soil profile descriptions loosely follow the terminology recommended by (1-3). Paleogeographic features were observed near several excavated sections, including paleochannels, erosional unconformities, and fossil termite mounds; fire-reddened earth and root casts were also noted.

Sedimentary units that contained pedogenic carbonates and other evidence of pedogenesis, including rootmarks, rootcasts, insect or small mammal burrows and/or vertic, blocky, crumbly, granular or platy structures, were targeted for sampling, although not all pedogenetic units were sampled. Samples that were collected comprise massive calcretes and fossil soils, many of which had carbonate nodules.

Samples for isotopic analysis were excavated with metal tools, placed directly into clean heavy-duty aluminum foil, and then sealed in polyethylene ziplock bags. Human contact with samples was rigorously avoided. Samples were air-dried in the sun by opening the bags but not unwrapping the foil; dryness was indicated by the absence of condensation inside the bags. Duplicate samples were taken for phytolith analysis. 
Clean carbonate samples were obtained by isolating the homogeneous centers of nodules by grinding and drilling with a diamond-embedded Dremel rotary tool burr. Sediments and carbonates were ground with a ceramic pestle and mortar to pass a $0.25 \mathrm{~mm}$ mesh sieve. For carbonate carbon and oxygen isotopic analysis, samples weighing $\sim 200 \mathrm{mg}$ were roasted under vacuum in $9 \mathrm{~mm}$ borosilicate culture tubes for four hours at $400^{\circ} \mathrm{C}$ to reduce organic carbon and remove clay hydroxyls and volatiles. Samples weighing $20 \mathrm{mg}$ were reacted with phosphoric acid under vacuum at $25^{\circ} \mathrm{C} \mathrm{(4)} \mathrm{and} \mathrm{resulting} \mathrm{CO}_{2}$ was purified by cryogenic distillation, and collected in sealed $9 \mathrm{~mm}$ pyrex tubes. $\mathrm{CO}_{2}$ yields were measured manometrically during distillation and carbonate carbon concentrations (weight $\% \mathrm{C}$ ) were calculated.

Samples were prepared for organic carbon isotopic analysis by treatment of 4-8 $\mathrm{g}$ of sediment or carbonate with $1 \mathrm{M} \mathrm{HCl}$, in acid-washed, annealed pyrex centrifuge tubes. $\mathrm{HCl}$ was changed twice daily until reaction ceased. Samples were rinsed to neutrality with distilled water and dried in a gravity oven at $70^{\circ} \mathrm{C}$. Approximately $850-1000 \mathrm{mg}$ of carbonate-free residue was placed in $6 \mathrm{~mm}$ Vycor (synthetic quartz glass) weigh boats in $9 \mathrm{~mm}$ Vycor tubes with $\sim 1.5 \mathrm{~g}$ copper oxide, $\sim 1.5 \mathrm{~g}$ pure copper and $\sim 40 \mathrm{mg}$ silver. In order to remove traces of refractory carbon and newly-adsorbed atmospheric carbon contaminants, elemental copper was pre-cleaned by roasting at $460^{\circ} \mathrm{C}$ for 6 hours under a partial hydrogen atmosphere with a liquid nitrogen trap; Vycor, silver and copper oxide were roasted in a muffle furnace at $520^{\circ} \mathrm{C}$ for three hours, and then at $800900^{\circ} \mathrm{C}$ for $1-3$ hours within one day of loading samples. Mortars and pestles were also acid-washed and annealed at $520^{\circ} \mathrm{C}$. This rigorous pre-cleaning procedure resulted in an undetectable background blank for organic $\delta^{13} \mathrm{C}$. After pumping under high vacuum for 20 hours to remove moisture and atmospheric contaminants, the 9 $\mathrm{mm}$ Vycor combustion tubes were sealed with a torch. Organic carbon was converted to $\mathrm{CO}_{2}$ by static (Dumas) combustion for three hours at $860^{\circ} \mathrm{C}$, followed by gradual cooling to $600^{\circ} \mathrm{C}$ over 12 hours, then to room temperature over 4 hours. $\mathrm{CO}_{2}$ was purified by cryogenic distillation immediately after combustion. $\mathrm{CO}_{2}$ yields were measured manometrically and organic carbon concentrations (weight $\% \mathrm{C}$ ) were calculated. Organic carbon combustion $\mathrm{CO}_{2}$ samples were sealed in annealed 6 mm pyrex tubes.

Isotope ratio mass spectrometry was performed at the Illinois State Geological Survey on a dualinlet, triple-collector Finnegan Delta-E isotope ratio mass spectrometer. Stable isotope ratios $\left({ }^{13} \mathrm{C} /{ }^{12} \mathrm{C}\right.$ and ${ }^{18} \mathrm{O} /{ }^{16} \mathrm{O}$ ) are reported, with ${ }^{17} \mathrm{O}$ corrections, as delta $(\delta)$ values in parts per thousand (permil - \%0) difference from the PDB carbonate international reference standard (Craig 1957), calculated as:

$\delta \mathrm{X} \% 0=\left[\left(\mathrm{R}_{\text {sample }} / \mathrm{R}_{\mathrm{PDB}}\right)-1\right] \times 1000$ where $\mathrm{X}$ is ${ }^{13} \mathrm{C}$ or ${ }^{18} \mathrm{O}$ and $\mathrm{R}$ is ${ }^{13} \mathrm{C} /{ }^{12} \mathrm{C}$ or ${ }^{18} \mathrm{O} /{ }^{16} \mathrm{O}$. To insure accuracy, international standards (NBS18 and NBS19) and working standards (Corydon calcite, supplied by J.M Hayes, Indiana University, and Sigma Chemical Co. thiourea) were prepared with each batch of pedogenic

carbonate and organic carbon samples submitted for mass spectrometry. The overall precision of the mass spectrometer is less than \pm $0.1 \%$ and replicate samples usually vary by less than $\pm 0.2 \%$.

References and notes:

P.W. Birkeland, Soils and Geomorphology. Oxford University Press, New York, (1984).

G.H. Mack, W.C. James, and C.H. Monger (1993). Geol. Soc. of Am. Bull. 105, 129-136(1993).

G.J. Retallack, Soils of the Past. Unwin Hyman, Boston, (1990).

J.M. McCrae, J. Chem. Phy. 18, 849-857 (1950) 